\title{
Experimental study on strength properties of concrete replacing cement by marble dust and sand by iron ore tailings
}

\author{
Naresh Kumar ${ }^{1 *}$, Brijbhushan. $S^{2}$, Maneeth.P.D ${ }^{2}$, Shreenivas.Reddy..$^{3}$ and Siddharth. ${ }^{2}$ \\ PG Student, Department of Construction Technology, VTU CPGS, Karnataka, India ${ }^{1}$ \\ Assistant Professor, Department of Construction Technology, VTU CPGS, Karnataka, India ${ }^{2}$ \\ Professor, Department of Construction Technology, VTU CPGS, Karnataka, India ${ }^{3}$
}

\section{(C)2018 ACCENTS}

\begin{abstract}
The present experimental study is carried out to find the behaviour of iron ore tailings (IOT) and marble dust by partially replacing fine aggregate (natural sand) at 10\%,20\%,30\%,40\% and ordinary Portland cement (OPC) at 5\% 10\%,15\%,20\% respectively for M40 grade concrete as per IS 10262-2009. The sample of IOT material for the present project is brought from Bellary district Karnataka. The test was carried on fresh and hardened concrete. It is found that as the percentage of IOT increase workability reduces. So admixture superplasticizer "CONPLAST-SP340" was used to maintain workability. The optimum replacement was found at 10\% IOT and 5\% marble dust based on strength properties.
\end{abstract}

\section{Keywords}

Iron ore tailings (IOT), Marble dust, Superplasticizer.

\section{Introduction}

According to a recent report by the World Health Organization (WHO), among world's 20 polluted cities, India is 14 based on particulate matter 2.5 levels in 2016 (published on May 1, 2018). It gives a clear indication of global warming because of not adopting the technology, which may lead to environmental problems in coming days.

It is a big challenge to the government to develop the country without harming the environment by using all the safety measure to protect the globe.

For every developing country, construction industry plays a very important role. In construction industries demand of steel and materials of concrete like aggregate, sand and cement is day by day increasing rapidly along with which is affecting the environment due to using of natural resources.

To avoid the use of natural resources to protect the environment many studies and researchers are going on to replace the natural resources by waste generated by industries like iron ore tailings (IOT) is replacing to natural sand and marble dust to cement. IOT is generated due to heavy demand for steel in the world and after the extraction of valuable ore.

\footnotetext{
*Author for correspondence
}

It is disposed of in open land which leads to land pollution. The waste produced is more than 10-12 million tons per year [1]. As it has very fine material property left over after the extraction of slurry, researchers suggest that instead of dumping IOT used as a substitute to fine aggregate.

Marble dust also has lots of demand for decorative purpose in building construction. From the quarry to finishing process more than $20-30 \%$ of waste generated which is very fine particle. If it deposes in open place it causes air pollution which is hazardous material to health as well to the agricultural land which reduces the fertilization of crop [2]. For its fineness property purpose, it is to be found by many recent past year scientists are trying to use in the building construction by replacing partially by cement to marble dust.

\subsection{Scope of the project}

Utilization of waste products in construction industries as partially or fully replacement in concrete and other building materials. Recent past years Iron ore tailings the large production in Indian steel industries due to heavy demand of construction. To reduce the environmental issues replacement of fine aggregate and cement as IOT and marble dust respectively plays an important role and it acts as an alternative method too. 


\subsection{Objectives}

The paper objectives are as follows:

1) Studying the properties and behavior of IOT and marble dust with conventional concrete.

2) Natural sand is replaced by IOT and cement by marble dust.

3) Studying the workability of concrete after replacing IOT \& marble dust for fine aggregate and cement respectively

4) Determining the mechanical strength properties of concrete after replacement.

\subsection{Literature review}

Kumar et al. [1] found that increase in percentage of the IOT decreases the workability, hence superplasticizer is necessary. Compressive strength concrete is more at $40 \%$ replacement of the IOT than the reference mix (NC).In case of the flexural reference, mix is maximum than the replacement.

Gopi [2] stated that compaction factor and strength increased up to $15 \%$ replacement of cement by marble dust and slump decreased as a percentage increased. Marble dust recognized as low costing material and keeps the environment safe. Test were carried out for partially replacement cement by marble dust to $0 \%, 5 \%, 10 \%, 15 \%, 20 \%$ and $25 \%$ for M30 grade concrete .

Ugama et al. [3] suggested that due to fine particles and more surface area, IOT reduces the workability. $20 \%$ of IOT replacement has got a closer compressive strength to the replacement of sand (RS). At the age of 28days curing for IOT replacement $43.67 \mathrm{~N} / \mathrm{mm} 2$ and $\mathrm{RS}$ is $45.02 \mathrm{~N} / \mathrm{mm} 2$ which values are close. Therefore $20 \%$ IOT replacement is limited and splits tensile strength gave good values than the RS.

Navale et al. [4] instructed to use admixture superplasticizer for workability and found that there is no effect on the compressive strength by substituting the natural sand. Got maximum compressive strength up to $40 \%$ of IOT replacement.

WP et al. [5] suggested that the compressive strength does not affect by replacing the natural sand by IOT, at $40 \%$ of partial replacement of IOT shows maximum and central deflection at compressive and flexural strength respectively. He stated that sand can be replaced by IOT to produce the concrete [5].

Kumar and Dhaka [6] suggested that the marble powder may be used as partial replacement of cement in a concrete. It enhances a property of concrete. It cost less compare to cement as marble dust is easily available in marble company. And also it helps to reduce the land pollution.

Singh et al. [7] suggested that in cement production units marble dust may be used up $10 \%$ as it does not influence to the setting time. Used material marble dust ratio enhances the specific gravity and reduces the area of the surface. In this study found that compressive strength is more as compared to the ordinary Portland cement (OPC).

Kumar and Kuma [8] suggested that up to $10 \%$ cement replaced with marble dust has given good results to test and up to $15 \%$ replacement split tensile and flexural strength increased thereafter reduced.

Alsadey [9] suggested that the adding limited superplasticizer as per the design increases the workability. It is concluded that superplasticizer helps to enhance the strength of concrete. If the superplasticizer dosage more than the required it will harm to the concrete.

Muhit [10] suggested from the results of the study, it is decided that by addition of superplasticizer the workability of concrete can be enhanced. By using the proper dosage of chemical admixture slump loss can be reduced to a great extent. In superplasticizer, the concrete effect is too high. Up to a specific limit $(1.0 \%)$ with the increment of superplasticizer dosage, the compressive strength is improved and it is compared with a control specimen which fabricated without any SP. The effective range of dosage is 0.6$1.0 \%$.

\section{Experimental investigation}

\subsection{Materials}

2.1.1Cement

OPC was used for the project conforms to the Indian standards IS 12269-1987 grade 53 (UtraTech). Following test has been carried out in the project as per IS: 4031-1998 [11]. Table 1 shows the physical properties of cement tested in the laboratory.

Table 1 Physical properties of cement tested in the laboratory

\begin{tabular}{lll}
\hline S. No & Characteristics & Results \\
\hline 1 & Fineness & $3.4 \%$ \\
2 & Initial setting time & $185 \mathrm{~min}$ \\
3 & Soundness & $1 \mathrm{~mm}$ \\
4 & Final setting time & $270 \mathrm{~min}$ \\
5 & Norman Consistency & $32 \%$ \\
6 & Specific gravity & 3.09 \\
7 & Final setting time & $270 \mathrm{~min}$ \\
\hline
\end{tabular}


2.1.2Coarse aggregates (CA)

$20 \mathrm{~mm}$ and $10 \mathrm{~mm}$ aggregates are used obtained from local crushers. The test was carried as per the IS: 2386.

Three trials were conducted for selecting the proportion of $20 \mathrm{~mm}$ and $10 \mathrm{~mm}$ coarse aggregate fraction. The Proportion for 50:50 and 60:40 of $20 \mathrm{~mm}$ and $10 \mathrm{~mm}$ coarse aggregate fraction did not give proper gradation. The proportion for 40:60 of $20 \mathrm{~mm}$ and $10 \mathrm{~mm}$ fraction of coarse aggregates was well graded. Hence this proportion is selected for present studies [12]. Table 2 shows the physical properties of coarse aggregates.

Table 2 Physical properties of coarse aggregates

\begin{tabular}{lll}
\hline S. No & Characteristics & Value \\
\hline 1 & Aggregate & Angular \\
2 & Free surface moisture & - \\
3 & Specific gravity & 2.2 \\
4 & Bulk density & \\
5 & a)Lose condition & $1.53 \mathrm{~g} / \mathrm{cm}^{3}$ \\
& b)Compacted condition & $1.748 \mathrm{~g} / \mathrm{cm}^{3}$ \\
6 & Abrasion value & 22.86 \\
7 & Impact value & 13.73 \\
8 & \%Water absorption & 0.67 \\
\hline
\end{tabular}

\subsubsection{Fine aggregates}

Natural sand has been used in our work. Test carried as per IS: 383-1970 [13].Test and results are in below Table 3

Table 3 Physical Properties of fine aggregates

\begin{tabular}{lll}
\hline S. No & Characteristics & Value \\
\hline 1 & Zone & II \\
2 & Fineness modulus & 3.87 \\
3 & Water absorption & 2.0 \\
4 & Specific gravity & 2.61 \\
5 & Silt content & Nil \\
\hline
\end{tabular}

\subsubsection{Water}

Portable water as ingredients in the concrete for casting and curing, water added as per the mix design. Water should use as per the standards IS: 456-2000 [14].

\subsubsection{Iron Ore Tailings (IOT)}

Waste material left after the extraction of valuable material from iron ore is known as tailings. The material was brought from Kej mineral, Bannehatti village, Torangal, Bellary district.

Table 4 shows the physical properties of IOT.
Table 4 Physical properties of IOT

\begin{tabular}{lll}
\hline S. No & Characteristics & Value \\
\hline 1 & Colour & Reddish brown \\
2 & Specific gravity & 2.66 \\
3 & Fineness modulus & 3.78 \\
4 & Optimum moisture content & $8.84 \%$ \\
5 & \%Water absorption & 15.87 \\
6 & Maximum dry density & $2.508 \mathrm{~g} / \mathrm{cc}$ \\
\hline
\end{tabular}

\subsubsection{Marble dust}

The material is which generates more than 20\%-30\% waste from the quarry to till finishing work in building construction for decorative purpose. The material used locally available granite and marble works industry [2]. Table 5 shows the physical properties of marble dust.

Table 5 Physical properties of marble dust

\begin{tabular}{lll}
\hline S. No & Characteristics & Results \\
\hline 1 & Specific gravity & 2.74 \\
2 & Colour & White \\
\hline
\end{tabular}

\subsubsection{Superplasticizer}

Superplasticizer is also called as "High Range Water Reducers" because without increasing the water workability can be achieved. In this experimental studies, Fosroc Conplast SP430 DIS used. Dosage decided by slump cone test by various trials.

\subsection{Mix proportion}

Mix proportion for M-40 grade concrete is after correction of water [15]. Table 6 shows the mix proportion.

Table 6 Mix proportion

\begin{tabular}{llll}
\hline Cement & $\begin{array}{l}\text { Fine } \\
\text { aggregates }\end{array}$ & $\begin{array}{l}\text { Coarse } \\
\text { aggregates }\end{array}$ & Water \\
\hline 1 & 1.43 & 2.628 & 0.496 \\
$437.7 \mathrm{~kg}$ & $625.6 \mathrm{~kg}$ & $1150.33 \mathrm{~kg}$ & $217.52 \mathrm{~kg}$ \\
\hline
\end{tabular}

\subsection{Mixing and casting}

Cubes has to be casted after cleaning and oiling to determine the compressive strength of IOT $10 \%, 20 \%, 30 \% \quad \& \quad 40 \%$ and marble dust $5 \%, 10 \%, 15 \%$ \& 20 respectively with addition of superplasticizer admixture.

\subsection{Batching}

It is the process of measuring the ingredients for concrete. Batching can be done by two methods. 
1. Volumetric/volume batching 2. Weigh batching Present experimental studies have been carried out by weigh batching method. Weigh batching is found that very convenient method for concrete mixing. Weigh batching may be differing from one project to another project as per the requirement/magnitude of the project. Ingredients to measure by as per standard procedure with accuracy of 0.5 grams.

\subsection{Mixing}

Mixing is a part of the concrete and it plays a vital role for homogeneous mix and gives good strength and durability of the concrete. Mixing has two methods:

1. Hand mixing

2. Machine mixing

The present study hand mixing adopted.

\section{Hand mixing}

Hand mixing is carried out in the small-scale construction project. It is done on the impervious plate, Concrete ingredients like cement, sand, aggregates, and water to weigh/measured as per the mix design and mix it by using the shovel manually till the homogeneous color achieved.

Natural sand is partially replaced by $10 \%, 20 \%, 30 \%$ $\& 40 \%$ and cement by marble dust $5 \%, 10 \%, 15 \%$ and $20 \%$ with water and also superplasticizer admixture added as per the design mix.

\subsection{Placing of concrete}

After mixing all the ingredients properly and placed the concrete in molds as per the IS code norms. Molds were cleaned and oiled than filled in three layers by 25 tamping using the $16 \mathrm{~mm}$ diameter and $600 \mathrm{~mm}$ length tamping rod for good compressive strength result.

\subsection{Curing}

The method adopted in this project is water curing by immersion. The concrete specimens were placed in the curing tank at the ambient temperature for curing. The concrete cubes are immersed in a water pond for 3 days, 7 days and 28 days.

\subsection{Fresh concrete tests}

\subsubsection{Slump test and compaction factor}

Both tests are carried out to find workability of concrete. The test is conducted where the maximum size of the aggregate should not be more than $40 \mathrm{~mm}$, the test can be carried out at the lab and also a site.

\subsection{Tests on hardened concrete}

\subsubsection{Compressive strength test}

This test conducted to know characteristics of concrete, it depends on many factors like w/c ratio, concrete ingredients, mixing, placing and curing. The casted cube to be tested on the compressive strength machine or universal testing machine (UTM), the tests are carried out after the curing period like 3days, 7 days, 28 days [16]. Figure 1 shows the flexuraltesting of specimen.

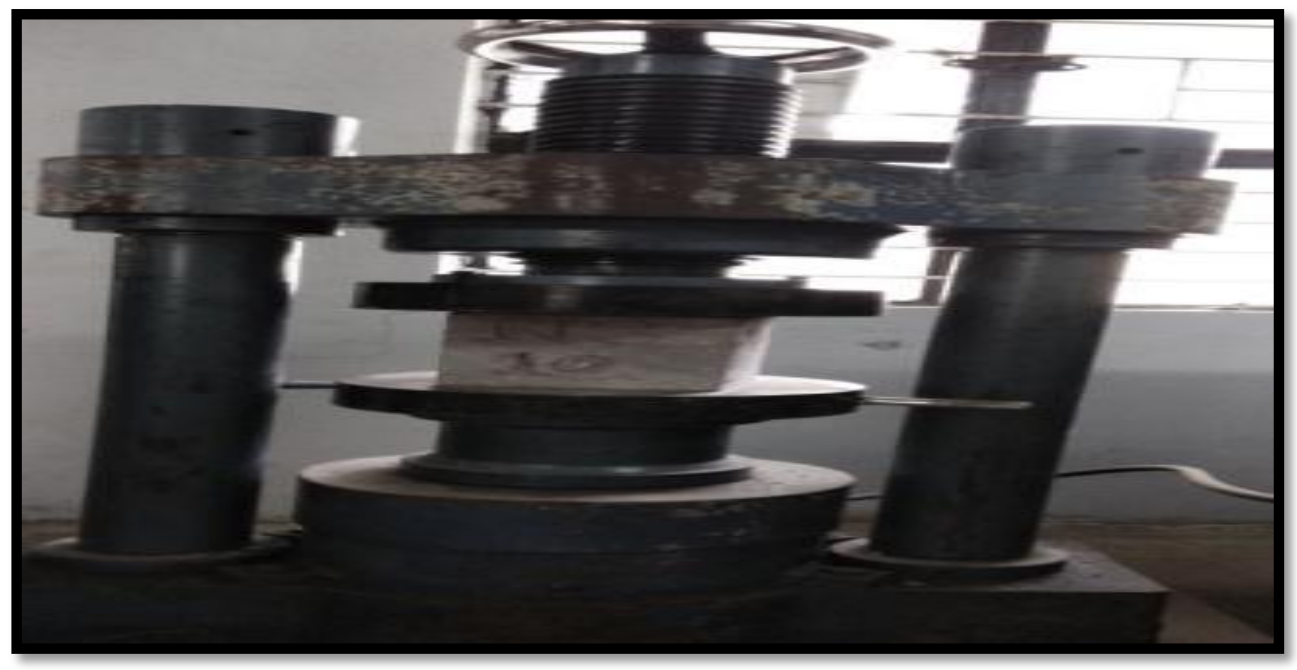

Figure 1 Flexural-testing of specimen

2.9.2 Split-tensile strength test

A cylinder size $150 \mathrm{~mm}($ dia. $) \times 300 \mathrm{~mm}$ (ht.) were prepared and tested under UTM [17]. Figure 2 shows the split-tensile strength of specimen. 
It can be calculated by using the Formula given below:

$$
\sigma=\frac{2 P}{\pi \mathrm{DL}}
$$

Where, $\sigma$ is the Split Tensile Strength $\frac{N}{m m 2}$

$$
\begin{aligned}
& \mathrm{P}=\operatorname{Load}(\mathrm{N}) \\
& \mathrm{L}=\operatorname{Height}(\mathrm{mm}) \\
& \mathrm{D}=\text { Dia. }(\mathrm{mm})
\end{aligned}
$$

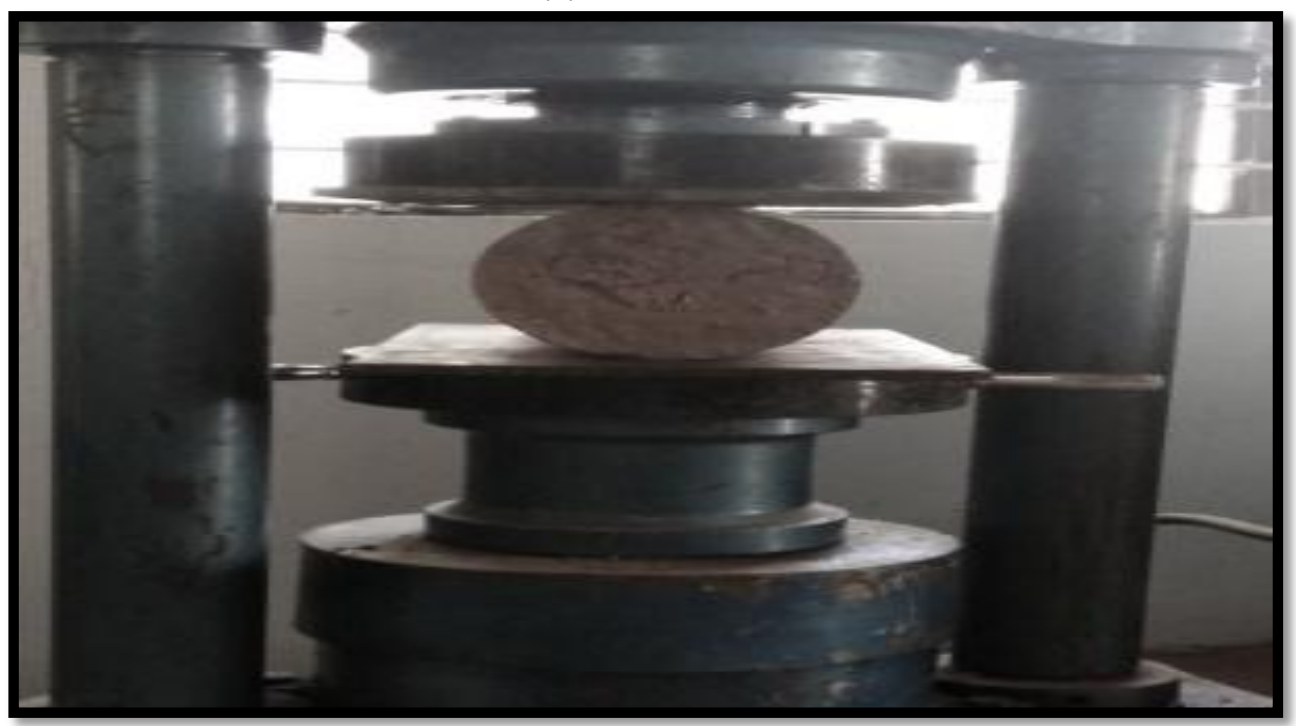

Figure 2 Split-tensile strength of specimen

2.9.3 Flexural-strength test

Test for different mix and different curing period 7 days and 28 days carried on the prism/ beam of size $100 \times 100 \times 500 \mathrm{~mm}$ casted and cured. The test results are calculated using the below formula. Figure 3 shows the flexural-testing of specimen.

$$
\mathrm{Fcr}=\frac{\mathrm{P} \times \mathrm{L}}{\mathrm{B} \times \mathrm{D}^{2}}
$$

Where: $\mathrm{F}_{\mathrm{cr}}=$ flexural-strength $\left(\frac{N}{m m 2}\right)$

$\mathrm{P}=\operatorname{Load}(\mathrm{N})$

$\mathrm{L}=$ Length $(\mathrm{mm})$

$\mathrm{B}=$ width (mm)

$\mathrm{D}=\operatorname{depth}(\mathrm{mm})$

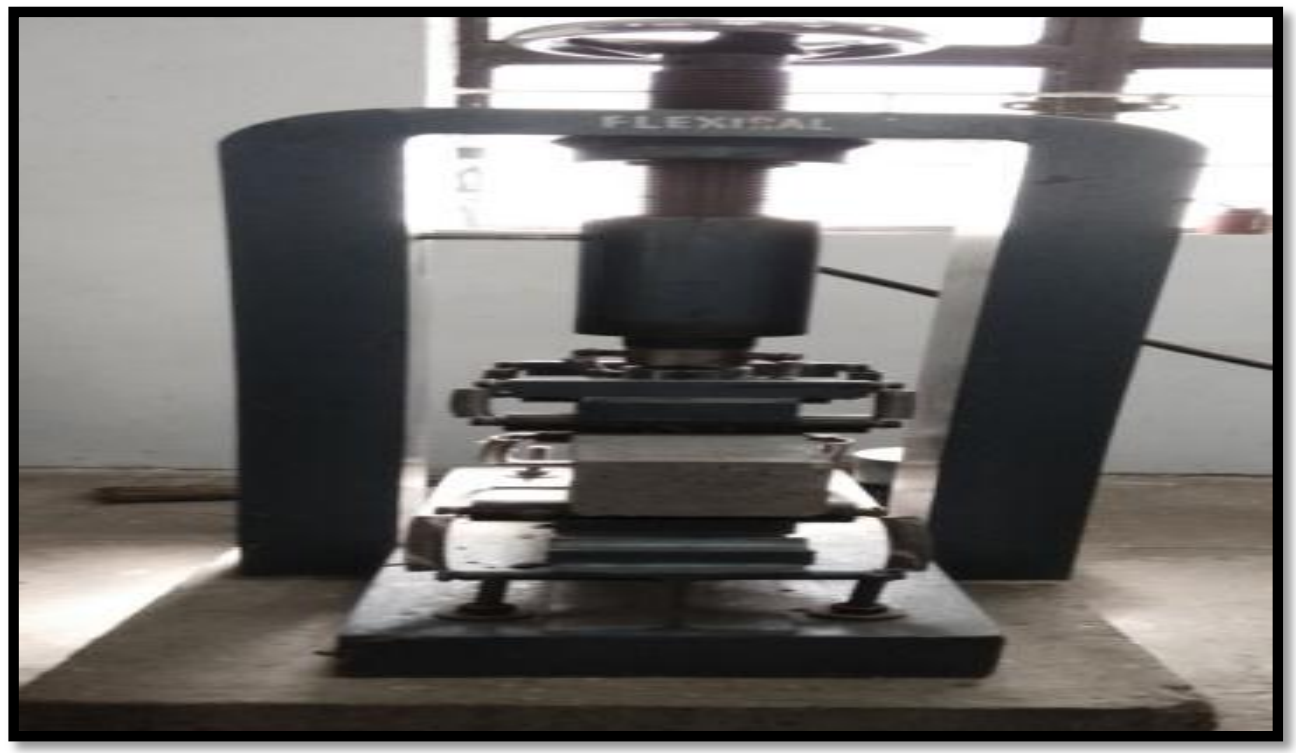

Figure 3 Flexural-testing of specimen 
kumar et al.

\section{Results and discussion}

Results of fresh concrete slump test and compaction factor test are carried to find the workability of concrete. The dosage of superplasticizer for all replacement levels are fixed based on slump test. Table 7 shows the slump cone result without superplasticizer.

Table 7 Slump cone result without superplasticizer

\begin{tabular}{lll}
\hline S. No & Mix Type & Slump value in mm \\
\hline 1 & C.C & 100 \\
2 & MX1 (10\%IOT, 5\%MD) & 95 \\
3 & MX2 (20\%IOT,10\%MD) & 25 \\
4 & MX3 (30\%IOT,15\%MD) & 0 \\
5 & MX4 (40\%IOT,20\%MD) & 0 \\
\hline MD: Marble dust &
\end{tabular}

Table 8 shows the slump cone result with Superplasticizer. Table 9 shows the replacement level increases and the slump value decreases.

Table 8 Slump cone result with Superplasticizer

\begin{tabular}{|c|c|c|c|}
\hline $\begin{array}{l}\text { S. } \\
\text { No }\end{array}$ & Mix type & $\begin{array}{l}\text { The } \\
\text { dosage of } \\
\text { SP (\%) }\end{array}$ & $\begin{array}{l}\text { Slump } \\
\text { value } \\
\text { in } \mathbf{m m}\end{array}$ \\
\hline 1 & $(10 \% \mathrm{IOT}$, & 0.15 & 105 \\
\hline 2 & $5 \% \mathrm{MD})$ & 0.5 & 90 \\
\hline 3 & MX2 $(20 \%$ IOT, $10 \%$ & 1.0 & 85 \\
\hline \multirow[t]{5}{*}{4} & MD) & 1.5 & 55 \\
\hline & MX3 & & \\
\hline & (30\%IOT,15\%MD) & & \\
\hline & MX4 & & \\
\hline & (40\%IOT,20\%MD) & & \\
\hline
\end{tabular}

Table 9 Compaction factor result with Superplasticizer

\begin{tabular}{lll}
\hline S. No & Mix type & Compaction factor \\
\hline 1 & Conventional & 0.9 \\
2 & MX1 (10\% IOT, 5\% MD) & 0.93 \\
3 & MX2 (20\% IOT,10\% MD) & 0.9 \\
4 & MX3 (30\% IOT,15\% MD) & 0.92 \\
5 & MX4 (40\% IOT,20\% MD & 0.9 \\
\hline \multicolumn{2}{l}{ MD: Marble dust }
\end{tabular}

\subsection{Results on hardened properties}

Table 10 shows that the compressive strength was maximum for conventional concrete $\left(51.7 \mathrm{~N} / \mathrm{mm}^{2}\right)$ considering all the mixes. Among all the replacement levels, mix 1 (10\% IOT and 5\% marble dust) had more compressive strength $\left(49.03 \mathrm{~N} / \mathrm{mm}^{2}\right)$.
Table 10 Results of compression test

\begin{tabular}{|c|c|c|c|c|}
\hline \multirow{2}{*}{$\begin{array}{l}\text { S. } \\
\text { No }\end{array}$} & \multirow[t]{2}{*}{ Mix type } & \multicolumn{3}{|c|}{ Compressive strength $\left(\mathrm{N} / \mathrm{mm}^{2}\right)$} \\
\hline & & 3days & 7days & 28days \\
\hline 1 & C.C & 18.81 & 32.14 & 51.7 \\
\hline 2 & Mix-1 & 13.62 & 22.21 & 49.03 \\
\hline 3 & Mix-2 & 15.4 & 25.03 & 42.36 \\
\hline 4 & Mix-3 & 13.18 & 21.32 & 32.88 \\
\hline 5 & Mix-4 & 13.03 & 21.18 & 28.43 \\
\hline
\end{tabular}

Table 11 shows that the split tensile strength was maximum for conventional concrete $\left(3.69 \mathrm{~N} / \mathrm{mm}^{2}\right)$ considering all the mixes. Among all the replacement levels, mix1 (10\% IOT and 5\% marble dust) had more compressive strength $\left(3.82 \mathrm{~N} / \mathrm{mm}^{2}\right)$.

Table 12 shows that the flexural strength was maximum for conventional concrete $\left(7.1 \mathrm{~N} / \mathrm{mm}^{2}\right)$ considering all the mixes. Among all the replacement levels, mix1 (10\% IOT and 5\% marble dust) had more compressive strength $\left(6.83 \mathrm{~N} / \mathrm{mm}^{2}\right)$.

Table 13 shows that, as the replacement rate level increases the water absorption rate increases in concrete mix.

Table 11 Results of split tensile strength

\begin{tabular}{llll}
\hline S. & Mix Type & \multicolumn{2}{c}{ Split tensile strength $\left(\mathbf{N} / \mathbf{m m}^{2}\right)$} \\
\cline { 3 - 4 } No & & 7days & 28days \\
\hline 1 & C.C & 2.63 & 3.69 \\
2 & Mix-1 & 2.54 & 3.82 \\
3 & Mix-2 & 2.12 & 3.67 \\
4 & Mix-3 & 2.12 & 3.62 \\
5 & Mix-4 & 1.79 & 3.1 \\
\hline
\end{tabular}

Table 12 Test results of flexural-strength

\begin{tabular}{llll}
\hline S. & Mix type & \multicolumn{2}{c}{ Split tensile strength $\left(\mathbf{N} / \mathbf{m m}^{2}\right)$} \\
\cline { 3 - 4 } No & & 7days & 28days \\
\hline 1 & C.C & 5.1 & 7.1 \\
2 & Mix-1 & 4.33 & 6.83 \\
3 & Mix-2 & 4.16 & 6.16 \\
4 & Mix-3 & 3.66 & 5.8 \\
5 & Mix-4 & 3.16 & 5.16 \\
\hline
\end{tabular}

Table 13 Durability test results

\begin{tabular}{lllll}
\hline $\begin{array}{l}\text { S. } \\
\text { No }\end{array}$ & Mix type & $\begin{array}{l}\text { Dry } \\
\text { weight } \\
\text { grams } \\
\text { (W1) }\end{array}$ & $\begin{array}{l}\text { Wet } \\
\text { weight in } \\
\text { grams } \\
\text { (W2) }\end{array}$ & $\begin{array}{l}\text { \% Water } \\
\text { absorption }\end{array}$ \\
\hline 1 & C.C & 8440.14 & 8468 & 0.33 \\
2 & Mix-1 & 8481.83 & 8520.5 & 0.45 \\
3 & Mix-2 & 8564.1 & 8609.5 & 0.53 \\
4 & Mix-3 & 8579 & 8642 & 0.74 \\
5 & Mix-4 & 8666.9 & 8745 & 0.9 \\
\hline
\end{tabular}




\section{Conclusion and future work}

Without superplasticizer, as the replacement \% increases the workability reduces. Superplasticizer at different dosage for all replacement increased workability. Compressive strength and split tensile strength for $5 \%$ marble dust and $10 \%$ IOT was more than normal concrete.

Flexural strength for normal concrete was more than all the replacement percentages. The optimum mix should be limited to $5 \%$ marble dust and $10 \%$ IOT in the concrete mix. Water absorption increases as the $\%$ of replacement increases in a durability test.

In place of cement, replacement uses some other binding material and studies the properties of concrete. Different durability tests like chloride penetration test, carbonation test can be conducted on all replacement tests. Future study can be made by changing water-cement ratio and using different admixtures.

\section{Acknowledgment}

None.

\section{Conflicts of interest}

The authors have no conflicts of interest to declare.

\section{References}

[1] Kumar BS, Suhas R, Shet SU, Srishaila JM. Utilization of iron ore tailings as replacement to fine aggregates in cement concrete pavements. International Journal of Research in Engineering and Technology. 2014; 3(7):369-76.

[2] Gopi R, Kaleeswari. G, Dhanalakshmi. G. Study on marble powder as partial replacement of cement in concrete. GRD Journals-Global Research and Development Journal for Engineering. 2017; 2(7):7780.

[3] Ugama TI, Ejeh SP, Amartey DY. Effect of iron ore tailing on the properties of concrete. Civil and Environmental Research. 2014; 6(10):7-13.

[4] Navale H, Nirmal S, Gund P. Effect on compressive and tensile strength of cement concrete road pavements due to use of Iron ore tailings as replacement to fine aggregate. International Research Journal of Engineering and Technology.2017; 4(11):1140-3.
[5] WP PK, MB A, K V. Effect of replacing sand by iron ore tailings on the compressive strength of concrete and flexural strength of reinforced concrete beams. International Journal of Engineering Research and Technology. 2014; 3(7):1374-6.

[6] Kumar R, Dhaka J. Review on use of marble powder as partial replacement of cement in concrete mix. International Journal for Technological Research in Engineering. 2016; 4(1):93-7.

[7] Singh R, Bhutani M, Syal T. Strength evaluation of concrete using marble powder and waste crushed tile aggregates. International Journal for Science and Emerging Technologies with Latest Trends. 2015; 20(1):18-28.

[8] Kumar MR, Kuma SK. Partial replacement of cement with marble dust powder. International Journal of Engineering Research and Applications. 2015; 5(8):106-14.

[9] Alsadey S. Effect of superplasticizer on fresh and hardened properties of concrete. Journal of Agricultural Science and Engineering. 2015; 1(2):704.

[10] Muhit IB. Dosage limit determination of superplasticizing admixture and effect evaluation on properties of concrete. International Journal of Scientific \& Engineering Research. 2013; 4(3):1-4.

[11] IS-12269:1987 codebook to conforming 53-grade cement.

[12] IS-2386 (Part 3) codebook for tests on coarse aggregate.

[13] IS -383:1970 codebook for grading of aggregate.

[14] IS 456-2000 codebook for the reference of mix design.

[15] IS 10262:2009 codebook for concrete mix design for Concrete.

[16] IS 516-1959 Indian standard code of practice methods of test for strength of concrete.

[17] IS: 5816-1999 Indian standard code for splitting tensile strength of concrete.

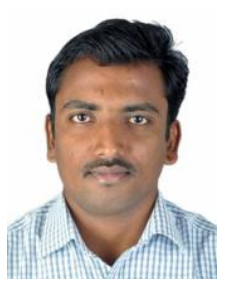

Naresh Kumar was born in 1986. He completed his Bachelor Degree in the RV College of Engineering Bangalore. At present, he is pursuing Master Degree in Construction Technology, VTU CPGS Gulbarga.

Email: naresh.rvce@gmail.com 